\title{
MEMÓRIA E REPRESENTAÇÃO FEMININA NO DIÁRIO DE HELENA MORLEY
}

\author{
MEMORY AND FEMALE REPRESENTATION IN HELENA MORLEY'S DIARY \\ Douglas FURTADO' \\ Fani TABAK ${ }^{2}$
}

\begin{abstract}
Resumo: Este artigo tem como objeto a obra "Minha vida de menina", diário escrito por Helena Morley entre 1893 e 1895, publicado somente em 1942. O intuito é analisar o diário sobre a perspectiva da memória, como elemento principal na narrativa e abordar a relação entre o contexto histórico, a memória e a literatura na obra. O trabalho visa discutir também a representação feminina presente na obra, por meio do ponto de vista da autora e do comportamento de outras mulheres presentes no diário.
\end{abstract}

Palavras-chave: Literatura brasileira; Helena Morley; Diário; Autobiografia.

Abstract: This article has as its object the work "My life as a girl", a diary written by Helena Morley between 1893 and 1895, published only in 1942. The purpose is to analyze the diary on the perspective of memory as the main element in the narrative and to approach the relationship between the historical context, memory and literature in the work. The work also aims to discuss the female representation present in the work, through the author 's point of view and the behavior of other women present in the diary.

Keywords: Brazilian literature; Helena Morley; Diary; Autobiography.

\section{Introdução}

O registro de um momento ou de determinado acontecimento é uma prática comum e necessária ao ser humano, presente desde as civilizações mais antigas. Essa prática se fez cada vez mais necessária na cultura contemporânea. Na medida em que o mundo se modernizou, a conservação da memória se tornou mais urgente. O progresso permitiu novas ferramentas e plataformas de conservação da memória.

\footnotetext{
${ }^{1}$ Graduado do curso de Letras Português-Espanhol da Universidade Federal do Triângulo Mineiro ${ }^{2}$ Docente do curso de Letras Português-Inglês da Universidade Federal do Triângulo Mineiro.
} 
As próprias redes sociais, hoje em dia, funcionam como uma importante ferramenta para guardar lembranças, podendo ser tanto lembranças significativas ou de arrependimento. Não importa o teor das lembranças, mesmo as que se valem do jargão popular, "expondo a vergonha alheia", ainda assim são um exemplo de um apontamento importante e útil de uma vida, sobrevivendo ao passar do tempo. As informações contidas nessas lembranças são conservadas, podendo em certo tempo serem reavaliadas ou revividas.

O diário é um suporte, comumente utilizado para guardar lembranças, uma forma de literatura íntima, autobiográfica. É normalmente utilizado para anotações pessoais, onde são apontadas informações íntimas ou ligadas ao cotidiano. Qualquer pessoa, não importa a idade e o momento em que se encontra, pode escrever um diário. No entanto, conforme acentua Lejeune (2008), há mais chances de se começar um diário na adolescência e principalmente por meninas. O objeto de análise deste artigo é justamente um diário, aparentemente escrito por uma menina em sua plena adolescência.

Minha vida de menina resgata o diário escrito por Alice Dayrell Caldeira Brant (1880-1970), com o pseudônimo de Helena Morley, entre seus 13 e 15 anos, em que relata o cotidiano de Diamantina em pleno século XIX, período esse marcado pela abolição da escravatura. Os relatos do diário abrangem o período de 1893 a 1895, contudo o diário foi publicado em 1942, época em que a autora tinha 62 anos.

Helena Morley, uma menina magra, sardenta e rebelde, filha de Alexandrina Brandão Dayrell e Felisberto Moyrell Dayrell, nasceu em 28 de agosto de 1880 em Diamantina. Seu pai, um minerador que viajava por várias regiões de Diamantina em busca de ouro e diamantes, veio a se casar com Alexandrina Brandão que fazia parte de uma tradicional família mineira. Fora Helena, seus pais tiveram mais três filhos: Felisberto Dayrell Junior, Tereza Dayrell e João Brandão Dayrell, sendo que Helena era a mais velha dentre seus irmãos.

Helena tinha ascendência inglesa, por parte de seu avô paterno, que foi um conceituado médico inglês e da família de seu pai, mantinha apenas contato com sua tia Madge, que tentava Ihe ensinar noções de etiqueta. Mas Helena praticamente convivia com a família de sua mãe, sendo que sua avó materna, seus tios e primos tinham condições financeiras melhores. Em 1900 Helena se casou com seu primo Augusto Mário Caldeira Brant.

A propósito, o marido de Helena, que no diário ganha o pseudônimo de "Leontino", ajudou na escolha do pseudônimo de "Helena Morley". O sobrenome 
Morley foi retirado do nome "Alice Morley Dayrell", a avó inglesa de Helena. A maioria das pessoas apresentadas no diário são nomeadas através de pseudônimos, por exemplo, os pais de Helena no diário são chamados de "Carolina" e "Alexandre", enquanto os irmãos de Helena de "Renato, Luisa e Nhonhô".

Uma das prováveis razões que levou Helena a utilizar pseudônimos é que muitos dos acontecimentos narrados na obra não abrangem apenas aspectos pessoais que dizem respeito à própria autora, mas que também envolve outras pessoas, muitas delas pertencentes ao círculo íntimo de Helena, sejam familiares ou amigos. Esse aspecto leva a autora a utilizar pseudônimos em seu diário para preservar o anonimato de pessoas próximas.

O uso dos pseudônimos, ainda não só protegeu a autora e pessoas próximas a ela, como anuncia o que Schwarz entende por teor de um realismo de formação social:

Ao experimentar-Ihe o teor, bem como a produtividade e os impasses, e sobretudo ao refletir sobre seus resultados e prolongamentos, entramos em contato com o movimento e com a lógica de uma formação social, o que em fim de contas é o desiderato moderno da literatura realista, aqui alcançado como em poucos romances da literatura brasileira - por uma obra que não é de ficção (1997, p.50).

A ideia do pseudônimo como proteção faz todo sentido se levarmos em conta que as anotações de Helena não se estendem meramente ao plano da ficção, como uma construção literária. As anotações colocam em jogo aspectos ligados com as próprias relações sociais, mesmo que se trate o diário como uma invenção, o mesmo imprime uma lógica ao mundo que se vê representado.

O uso do pseudônimo serve também como uma forma de máscara para a autora, principalmente por se tratar de uma mulher; nesse sentido é como se Helena não tivesse a intenção de que o diário apontasse a figura real da mulher "Alice Dayrell Caldeira Brant", mas sim que ela fosse sobreposta a uma outra mulher, uma personagem que escreve. A proteção autoral é uma forma de se resguardar de possíveis inconvenientes causados por sua escrita.

Há de se abrir um parêntese, uma breve observação sobre os documentos originais do diário de Helena Morley, para não incorrermos no erro de fechar os olhos perante informações que se apresentam em torno da análise da obra. Roberto Schwarz aponta o fato de que os "originais haviam sido queimados, e aliás nunca existiram - pois a obra na verdade seria o rearranjo de um anedotário familiar, além 
de estarem a salvo, guardados num baú. " (1997, p.46). Essa afirmação pode apresentar certa contradição, quando diz que os originais foram queimados (pressupondo a existência real dos documentos) e afirmando ao mesmo tempo que eles nunca existiram.

Não se pode ignorar que ao mesmo tempo em que a autora possa ter publicado seu diário com o apoio de algumas anotações, como ela mesmo diz em nota do diário, "Esses escritos que enchem muitos cadernos e folhas avulsas [...]" (MORLEY, 1998, p.13), ela também pode não ter deixado de aliar alguns dados fictícios com a construção literária, fazendo do diário uma narrativa literária. Não se pode deixar de levar em conta, ainda, a própria ideia do pseudônimo "Helena Morley" como uma personagem, fruto da criação da autora Alice Dayrell Caldeira Brant. Personagem esta, mergulhada em um contexto histórico vivido realmente pela autora.

Duas curiosidades saltam aos olhos sobre a obra de Helena Morley: a primeira é que o diário chegou a ser traduzido para o inglês pela escritora americana Elizabeth Bishop, que inclusive esteve no Brasil e visitou alguns lugares descritos no diário. A outra curiosidade, na verdade uma observação, é sobre o reconhecimento do diário por parte de intelectuais e escritores. No rol de admiradores da obra estão Carlos Drummond de Andrade e Guimarães Rosa.

\title{
O Diário
}

Como podemos ver no início da "nota à $1^{\circ}$ edição do diário", um dos grandes incentivadores para Helena escrever seu diário foi justamente seu pai:

\begin{abstract}
Em pequena meu pai me fez tomar o hábito de escrever o que sucedia comigo. Na Escola Normal o professor de Português exigia das alunas uma composição quase diária, que chamávamos de "redação" e que podia ser, à nossa escolha, uma descrição, ou carta ou narração do que se dava com cada uma. Eu achava mais fácil escrever o que se passava em torno de mim e entre nossa família, muito numerosa (MORLEY, 1998, p.13).
\end{abstract}

O fato do pai de Helena sugerir-lhe que escreva um diário está ligado a um "condicionamento histórico", o qual Lejeune comenta em "O pacto autobiográfico" (2008). Segundo o autor, o diário representava para as meninas que se 
encontravam na adolescência, uma espécie de cultura em grupo e também um rito de iniciação. No século XIX era comum as meninas serem estimuladas a escrever em um diário o que se passava com elas, como forma de resgatar os acontecimentos para si e para sua tutela. Enquanto o homem dispunha de mais liberdade, com a mulher acontecia totalmente o contrário, seu espaço era mais limitado, por isso o diário pode ser visto como um espaço de introspecção, mais favorável ao exercício da condição da mulher. A prática de escrever um diário pode não ser frequente nos dias atuais, mas antigamente era uma prática inteiramente comum e incentivada tanto pelos pais como pelos professores nas escolas.

A narrativa autobiográfica de Helena Morley, narrada sobre a forma de um diário, inevitavelmente levará os relatos contidos no mesmo para o campo da memória. Segundo Clara Rocha (1977, p.64), amparada pela tese de Thibaudeau, a autobiografia representa o momento em que o romancista faz intervir a memória e projeta sua vida (língua, cultura, ideologia), em que o texto é justificado pela sua assinatura, o "eu" se retrata e se inventa. O diário íntimo pode ser visto como uma das formas da literatura autobiográfica, em que fazem parte também as confissões, o ensaio autobiográfico, o auto-retrato, as memórias e o romance autobiográfico.

O termo "diário" pode significar "em primeiro lugar, que é uma escrita quotidiana: uma série de vestígios datados" (LEJEUNE, 2008, p.259). A noção de vestígio é essencial para entender o funcionamento de um diário, considerando que as anotações do diário são construídas em um tempo presente para em um futuro terem sua releitura realizada pelo autor das mesmas. O inverso também pode acontecer e as anotações tidas como íntimas podem vir a ser publicadas como um material inédito para vários leitores.

Se o diário pode ser considerado como uma série de vestígios datados, o mais certo é dizer que é a memória que faz com que esses vestígios apareçam, venham à tona. A memória não apenas reativa esses vestígios, como permite a releitura dos mesmos, reconfigura o passado e exercita o sentido da memória. Ela instaura uma conexão com o passado, retendo informações que podem ser mantidas intactas ou mantendo apenas uma fração dessas informações. No estudo da narrativa autobiográfica o conceito de memória é primordial, abrangendo campos da psicologia, psicofisiologia e outras áreas: 
homem pode atualizar impressões ou informações passadas, ou que ele representa como passadas (LE GOFF, 1990. p. 419).

Estudar um diário é estudar o processo do tempo envolvido na confecção do mesmo e de como esses rastros incluem a passagem do tempo. A relação entre diário e tempo é uma questão bastante complexa, já que os vestígios de um diário não têm a função de "acompanhar o fluxo do tempo, mas a de fixá-lo em um momento-origem". (LEJEUNE, 2008, p.260). Por isso, os vestígios de um diário servem para demarcar uma série de lembranças e momentos que poderão ser recuperados mais tarde, em um tempo posterior.

Passado e futuro se entrecruzam na escrita de um diário, como se pode verificar nas palavras de Helena: "venho aqui contar a história do tempo antigo, para o futuro, como diz meu pai. Quem sabe lá se no tal futuro não haverá mais novidades do que hoje?" (MORLEY, 1998, p. 95). Um método utilizado na composição de um diário é marcação de datas, que servem como ferramenta de localização dos relatos perpetrados, permitindo fixar um determinado evento ou acontecimento.

O diário de Helena Morley é composto por um total aproximado de 275 entradas, todas datadas, tendo início em janeiro de 1893 e término em dezembro de 1895, no qual chama a atenção a continuidade das datas, pois estas nunca são sequenciais, havendo sempre uma distância de um ou dois dias entre si. Há, portanto, uma fragmentação dos relatos que são colocados em continuidade no diário. Conforme Lejeune, "As descontinuidades do diário são portanto, ordenadas em série e de novo tecidas como continuidades" (2008, p.296), isso configura uma reordenação do passado pela memória que tece uma ordem. Essa ordem é compreendida na medida em que "as entradas do diário formam unidades breves" (Schwarz, 1997, p.49).

O que torna a leitura de um diário atraente é justamente o desenrolar da memória ao longo da escrita, pois ela funciona como um catálogo de informações, museu de lembranças e também como força motriz. Na verdade, "um diário serve sempre, no mínimo, para construir ou exercer a memória de seu autor (grupo ou individuo)" (LEJEUNE, 2008, p.261).

A memória caminha junto com a escrita. O depósito de memórias de Helena é construído através da escrita, que seleciona e organiza as lembranças. Helena tem plena consciência do papel que a memória desempenha na escrita de seu diário: 
Cada dia acho mais razão no conselho de meu pai de escrever no meu caderno o que penso ou vejo acontecer. Ele me disse: "Escreva o que se passar com você, sem precisar contar às suas amigas e guarde neste caderno para o futuro as suas recordações". Se eu não tivesse este caderno poderia guardar na memória o caso tão engraçado que vi ontem? (MORLEY, 1998, p.68).

O trecho serve para ilustrar, a compreensão de Helena, de que ao escrever, ela está preservando suas memórias para o futuro, para depois relembrar, retomar essas mesmas lembranças, sendo isso possível por meio da escrita. Entramos, num ponto determinante, que é a escrita auxiliando a memória. É preciso considerar a memória no nível da linguagem, como fez o próprio Le Goff, amparado pelos estudos de Henri Atlan:

\begin{abstract}
A utilização de uma linguagem falada, depois escrita, é de fato uma extensão fundamental das possibilidades de armazenamento da nossa memória que, graças a isso, pode sair dos limites físicos do nosso corpo para se interpor quer nos outros, quer nas bibliotecas. Isto significa que, antes de ser falada ou escrita, existe uma certa linguagem sob a forma de armazenamento de informações na nossa memória (LE GOFF, 1990 apud ATLAN, 1972, p. 461).
\end{abstract}

Pensar a memória como uma extensão da linguagem, pois o que é a memória se não o registro de pensamentos, que são expressos através da linguagem, seja por meio da oralidade ou da escrita. A linguagem é armazenada na memória. Dessa forma, ela ultrapassa os limites do espaço e do tempo, transforma-se em objeto fluido, dinâmico.

A memória executa uma ação passiva e ativa no diário, pois ali se comportam as memórias do passado e ao mesmo tempo a memória do presente, que justamente se encontra com essa memória passada. Segundo Lejeune, "o diário será ao mesmo tempo arquivo e ação, "disco rígido" e memória viva". (2008, p.262). Como bem ressaltam Tabak e Freire, recuperando as ideias de Jean-Yves Tadié e Marc Tadié: "a memória é função cerebral que estrutura o espaço entre aquilo que percebemos do mundo exterior e o que criamos ou construímos, aliados aos sentidos do que fomos e do porvir". (p.77, 2009). Escrever um diário é lançar um baú na linha do tempo, pois: 
lançada ao mar. Também investimento. $O$ valor de informação de um diário aumenta com o tempo (LEJEUNE, 2008, p.262).

É possível que no instante em que estava escrevendo seu diário, Helena se preocupasse com o momento presente, mas ela também de certa forma estava moldando lembranças e acontecimentos para serem apreendidos em um tempo posterior, no futuro. Um modo de se reequilibrar, de se encontrar com seu passado, consigo mesma.

Mesmo depois de sua publicação, em 1982, a memória em "Minha vida de menina" ainda tem o poder de agir e despertar sentimentos e emoções, pois sobrevive, permanece, mantém seu ritmo. Nessa direção, o diário pode ser visto como uma obra híbrida, que mescla e une a ficção, a memória e a história.

\section{História, Literatura e Memória no Diário de Helena Morley}

Pesavento em seu estudo sobre a história e a literatura, afirma que a "história se valia da literatura como um recurso ilustrativo de uma afirmação sobre o passado, para confirmação de um fato ou ideia. " (PESAVENTO, 2003, p.32). O diário utiliza a memória como resgate e construção de uma narrativa, que se enquadra em um tempo histórico determinado, mas sofre ação do momento da enunciação. Essa força inerente ao diário, enquanto relato, leva-nos a compreender a experiência da memória como um:

[...] processo de articulação frente ao seu pensamento na realidade, como mola propulsora da experiência do ser e do existir. A experiência narrativa da memória ergue-se entre o plano da imaginação criativa e as reminiscências vividas, reconstruídas a partir de fragmentos (TABAK; FREIRE, p.79).

Helena, em nota da primeira publicação do diário têm consciência de que não conseguiu escapar da continuidade inevitável do tempo, que ficou um espaço em aberto entre a vida que teve quando menina e a vida de adulta no presente. A autora visa transformar suas memórias em narrativa, justamente mostrando que o mundo mudou e que indivíduos acompanharam essas mudanças. Para tal intento ela apresenta o passado para uma nova geração, como podemos ver no respectivo trecho: 
Esses escritos, que enchem muitos cadernos e folhas avulsas, andaram anos e anos guardados, esquecidos. Ultimamente pus-me a revê-los e ordená-los para os meus, principalmente para minhas netas. Nasceu daí a ideia, com que me conformei, de um livro que mostrasse às meninas de hoje a diferença entre a vida atual e a existência simples, que levávamos naquela época (MORLEY, 1998, p.13).

Esse trecho apresenta a própria reflexão que Alice/Helena tem da modernização, pois não apenas o mundo como um todo mudou, se modernizou, mas o próprio individuo acabou sentindo o impacto dessa modernização. Helena ao se referir ao seu passado de menina como uma "existência simples", afirma que a sua existência atual é mais complexa.

Necessário analisar o diário não apenas sobre a perspectiva de uma série de anotações escritas por uma adolescente, de foro íntimo, mas também sobre a perspectiva de que esse diário se tornou uma obra literária. A compreensão de que as memórias até então pertencentes senão a Helena, agora são lidos e compartilhado por outras pessoas.

Alexandre Eulálio (1998) em prefácio da obra, diz que o diário é um meio caminho do documento e da ficção, caderno de anotações escritos à margem da literatura e se assemelha com a literatura picaresca. Essa afirmação de que o diário "é um meio caminho do documento e da ficção" refere-se ao fato de que o diário não deixa de ser um conjunto de documentos, no caso o registro de memórias vividas, e também não deixa de ser uma narrativa de relatos que utilizam a ficção como suporte dos fragmentos.

Em um dos relatos do diário, Helena conta sobre o dia em que seu irmão Renato estava doente e seu tio Geraldo, um dos parentes mais abastados da família e padrinho do menino, enviou-lhe de presente dez mil réis. Helena diante dessa situação saiu gritando que "como não temos sino, vamos bater mesmo uma lata. Hoje tem festa no céu. Tio Geraldo lembrou-se de dar um presente a Renato depois que ele está com quinze anos." (MORLEY, 1998, p. 93). A conduta de Helena gritando sobre o comportamento de seu tio ganha contornos de sátira considerando que ela deixa evidente que a atitude do seu tio está vinculada a uma questão socioeconômica.

Essa cena coloca em xeque o funcionamento das diferenças de classes sociais numa mesma família, pois Helena e seus irmãos pertencem à parte mais pobre da família, enquanto Tio Geraldo é da parte mais rica. A atitude de Geraldo de 
presentear o irmão de Helena está ligada a uma obrigação, conveniência, simplesmente porque é o padrinho do menino. Não percebemos uma atitude de preocupação do tio, levando em conta que nem se deu ao trabalho de levar o presente pessoalmente. A leitura deste episódio demonstra como um simples relato que poderia se tornar banal pode apresentar questões importantes e complexas com um toque de humor e ironia, que conforme afirmação feita por Schwarz, um dos grandes milagres do livro é justamente "que ele não se afasta do dia a dia da província e entretanto não resvala para o anódino" (1997, p.64).

Em outro episódio do diário, Helena conta com toques de humor o dia em que ela usou da esperteza e malandragem para com sua irmã, para conseguir seus objetivos e diz "Vou escrever aqui o que eu fiz com ela e não tenho vergonha, por que é só o papel que vai saber" (MORLEY, 1998, p.78). Neste trecho a autora fala do acontecido sem pudor ou medo de julgamento, tendo a ideia de que o acontecimento ficará apenas no papel.

Um ponto curioso sobre o livro é que os diálogos presentes nos relatos são mantidos por Helena. Ela transcreve os diálogos da forma que aparentemente aconteceram, havendo um encontro entre a norma culta e o registro coloquial. $A$ oralidade é um elemento bastante forte na obra, pois muitos dos acontecimentos relatados no diário são acompanhados da própria fala dos personagens envolvidos.

A aplicação do uso coloquial no diário é visível, considerando que a autora aproxima o seu leitor da fala de Diamantina do século XIX. Claramente vemos que alguns fragmentos demonstram a presença da oralidade na escrita do diário:

A mulher, Dona Mariquinha, dizia sempre que nos via: "Que saudades da Quitinha! Vendo a sua menina, parece que estou vendo a outra, Dona Carlolina. È cara duma, cara doutra, sem tirar nem pôr. Ainda hei de juntar as duas para a senhora ver". Mamãe dizia: "É pena mesmo a sua não estar aqui”. Ela dizia: "O dia chegará, Dona Carolina" (MORLEY, 1998, p.21).

- A senhora então ainda não soube?

- Não! - respondi. - O que foi?

- Siá Donana tornou a viver.

- Como? Pois ela não estava morta?

- Morta ela tava, isto é, não tava, mas parecia que tava. Pra mim ali tem coisa-feita, mas a gente não pode mesmo tá falando. A senhora já viu uma pessoa morta fica só escutando o que os vivos tão falando? (1998, p.261).

Volto-me para os meninos e digo:

- Então, ninguém estudou a lição hoje?

- Não mestra; quase todos enganaram a senhora.

- Eu não!

- Enganou sim; ocê tava adiante!

[...] Xi, tomou pito! Xi, tomou! (1998,p.278). 
Vovó perguntou: "Que é isto? Aonde Vão todos assim?"

Foi Benfica que respondeu: "Giniroso não viu treva. Bom; Giniroso não viu treva. Giniroso não viu lava-pé. Bom; Giniroso não viu lava-pé. Giniroso e nós tudo não vê inforcá o juda que vendeu Nossinhô, oncê não vê que não é possive?".

Vovó respondeu: "É isso mesmo, têm toda a razão, podem ir". (1998, p. 139).

A oralidade não se faz presente apenas na transcrição dos diálogos, mas na própria narração de Helena, tendo em vista que uma leitura atenta e detalhada revela a riqueza da construção dos relatos narrados pela autora. Uma das qualidades de seus relatos está justamente no discurso narrativo empregado pela mesma, pela forma com que o narrador tece desde o léxico utilizado até o diálogo com o contexto histórico da época e com o próprio ambiente que está sendo criado. No livro encontramos o papel da memória no discurso narrativo através de uma linguagem coloquial simples utilizada pela narradora compondo o olhar da mulher em pleno fim do século XIX, como nos mostra o seguinte fragmento:

\begin{abstract}
Tenho visto muita coisa na vida, mas padre mexeriqueiro foi hoje a primeira vez. Eu estava na porta, quando vi Padre Augusto vir descendo do Palácio e caminhando para a Chácara. [...] Chamo vovó; ela toda inchada com a visita, pega na bengala, segura no meu braço e vamos para a sala. Mamãe, Dindinha, laiá e tia Agostinha foram também para a sala conversar com o padre. [...] Deixei todas ali e voltei para dentro. Nós sempre aproveitamos toda a ocasião para irmos para a ribanceira. Chamei o pessoal todo: Nico, Renato, Nhonhõ, Luisinha e Rita, e voamos para o fundo da horta. Tínhamos escorregado só uma vez e quando demos fé estava a velharia toda no alto, olhando o que estávamos fazendo. (MORLEY, 1998, p. 44).
\end{abstract}

A linguagem simples se faz presente na utilização de palavras e expressões como "mexeriqueiro", "inchada com a visita", "voamos para o fundo da horta" e "velharia toda no alto". Todas essas expressões utilizadas servem para presentificar a voz da menina, aproximando a fala da personagem Helena Morley com o seu leitor.

Helena mantém em todo seu discurso uma jovialidade, alegria e vivacidade, , que mostra as energias e gracejos próprios da meninice. Um episódio que podemos utilizar como exemplo é quando a autora diz "a coisa que mais gostamos é ficar descalços, com o pé molhado, subindo e descendo o desbarranque da lavra, procurando diamantinhos e folhetas de ouro [...]" (MORLEY, 1998, p. 23). O adulto descreveria o ofício de extrair diamantes em uma lavra de forma séria, como algo rotineiro, mas Helena ao contrário descreve este fato como algo prazeroso, dizendo 
que ela e todos os meninos gostavam de ficar com os pés descalços e molhados. O trabalho destinado aos adultos ganha contornos de brincadeira; a forma com que descreve esse momento se aproxima do lúdico.

Um dos motivos que contribui para que dos relatos de Helena emane uma sensação de vitalidade e frescor é o desabafo, que pode ser visto como outra utilidade do diário, que permite a criação de um espaço momentâneo, em que a autora fique livre das amarras sociais e da influência individual e coletiva. $\mathrm{Na}$ verdade, "o diário é um espaço onde o eu escapa momentaneamente à pressão social, se refugia protegido em uma bolha onde pode se abrir sem risco, antes de voltar, mais leve ao mundo real." (LEJEUNE, 2008, p.262).

Esse espaço de desabafo permite que Helena circunscreva seu eu individual. Assim, constrói-se sua voz, seus pensamentos e impressões, como nos mostra o seguinte exemplo:

Eu não penso como mamãe. Não falo nada porque em negócio de religião ela não admite discussão. Não posso ter esse medo que mamãe tem porque eu penso comigo: "Se meu pai for para o inferno, para onde irão meus tios e todos os homens de Diamantina a não ser Juca Neves?" Eu sei que Deus é justo (MORLEY, 1998, p.103).

O que se percebe no trecho acima é que a reflexão religiosa que Helena tem não vai ao encontro da noção de religião de sua mãe e de outras pessoas, noções essas regidas por normas institucionalizadas. Helena vê a religião mais como uma força interior, um aspecto inerente ao ser humano, uma visão filosófica que não se aproxima da ideia de religião como uma instituição capaz de determinar a tudo e a todos. Segundo Schwarz:

O livre exame das questões e sobretudo das instituições e tradições consagradas define a fisionomia intelectual de Helena, que deriva dele um evidente sentimento de superioridade e distância em relação ao meio, mas também a abertura de espírito que permite entendê-lo (SCHWARZ, 1997, p.80).

Um dos triunfos da obra reside justamente nos valores morais e reflexões que Helena dispara aos olhos dos leitores mais atentos, que vão perceber que fogem totalmente dos valores institucionais já arraigados em grande parte da sociedade de Diamantina. Enquanto certas pessoas julgam certos comportamentos como sendo 
motivo de ir para o inferno, Helena pensa diferente, pois suas ideias não estão submetidas a um discurso ideológico do senso comum.

Nesse ponto, é necessário falar sobre o discurso narrado por Morley e o discurso histórico que se apresenta diante dessa narração. O olhar de Helena Morley para cada tema e situação narrada no diário, se estabelece diante do momento de enunciação em oposição ao discurso histórico. Vejamos o seguinte trecho:

Este ano saiu à rua a procissão de cinzas que há muitos anos não havia. Não sei como eles não faziam mais uma procissão tão importante, como todos santos. [...] Quando eu era pequena, eu podia acreditar nisso, hoje sei que é bobagem. (MORLEY, 1998, p. 36).

O trecho evidencia um distanciamento no texto, ficando claro uma transformação do diário em uma autobiografia. Aqui temos uma narração fixada no presente, mostrando o momento exato em que a autora concentra toda suas ideias e pensamentos em favor da narrativa; ao mesmo tempo que a narradora mostra um referente histórico, a enunciação se contrapõe à narrativa histórica.

Helena reflete assim dois momentos distintos, uma em que acreditava nessas histórias, em que tinha um tom de ingenuidade e credulidade e outro, em que prevalece uma consciência crítica dos fatos. Este fragmento serve para apresentar a perda da inocência por parte da autora, porque muitas vezes é no próprio ato da escrita que a pessoa acaba tomando conhecimento de determinadas coisas. $O$ próprio resgate da memória acaba funcionando como descoberta, como autoconhecimento. Funcionado como um espelho, o diário permite à autora conhecer-se a si mesma, ver-se transformada.

$\mathrm{Na}$ frase "Quando eu era pequena, eu podia acreditar nisso, hoje sei que é bobagem", o uso das palavras "Quando" e "hoje" levantam a questão da distância temporal. A palavra "quando" é utilizada como forma de resgate da memória. Esta frase evidencia que no momento da narração há um resgate das suas lembranças "que nos levam à fronteira onde a memória se torna "história" (LEGOFF, 1990. p. 430).

O diário, portanto, tenciona o tempo da narrativa e o tempo da narração. Um ponto importante que deve ser registrado, é que o diário nunca vai apresentar um fato narrado com toda a precisão de um tempo presente. Há sempre um retrocesso, 
um espaço vago no meio da narrativa. No momento em que você resolve transpor um determinado fato ocorrido para o papel, um tempo foi transcorrido, sejam segundos, minutos, horas ou até dias. O diário permite conservar e registrar memórias, mas também destruir e reformular pensamentos. No processo de escrita Helena muitas vezes pondera algumas mudanças de valores: "Eu de pequena, tinha inveja muitas vezes, mas hoje não tenho" (1998, p.148). Esse "hoje não tenho" é uma marca precisa do tempo da narração.

Clara Crabbé Rocha em "O espaço autobiográfico em Miguel Torga” aborda essa questão do tempo da narração e do tempo da narrativa, no seguinte fragmento:

[...] a autobiografia pressupõe, como veremos, um desvio temporal e de identidade que se estabelece entre o eu actual (narrador e pessoa do autor) e o eu passado (personagem retratada). A coerência da forma autobiográfica reside simultaneamente na diferença e na proximidade que existem entre o sujeito e o objeto da enunciação (ROCHA, 1977, p.65).

Helena é personagem e narradora de sua própria história. Ao contar sua história, nos apresenta duas identidades, a da Helena como personagem, inserida no passado e a Helena autora, com o poder da escrita. A distância temporal que se apresenta no diário permite que o narrador tenha duas posturas diante da personagem narrada, tanto de reconhecimento diante da personagem como de não reconhecimento. O que se verifica é que:

[...] simpatia e antipatia são as duas atitudes possíveis do narrador autobiográfico, e advêm da estreita ligação entre este e a personagem narrada. O autobiográfico diverge pois do biógrafo, na medida em que, por coerência, nunca aspira a uma atitude exemplar de empatia (ROCHA, 1977, p.53).

Segundo Rocha (1977), a convergência do eu passado com o eu atual apresenta a sua indiciação linguística, como se verifica em uma certa parte do diário, quando Helena diz que "Tenho certeza de que esses livros não me valeram de nada. Força de vontade não adquiri nem um pingo mais do que tinha" (MORLEY, 1998, p.58). O trecho permite apreender a confluência do passado com o presente narrado no uso do verbo ter, no presente do indicativo, indicando o eu atual, na rememoração de uma situação passada. 
Um exemplo que revela as marcas do encontro dos pensamentos da narradora adulta com as memórias da menina na narrativa faz-se no que se refere às lembranças de Biribiri, uma vila que se encontra dentro do município de Diamantina. Em certa parte do diário, Morley diz: "Chegamos hoje do biribiri, onde passamos três dias de gozo completo. Eu não teria pressa de ir para o céu se morasse no Biribiri. Não acredito que no céu se possa ter melhor vida do que ali". ( 1998, p.54).

A felicidade de Helena nesse trecho é visível, sendo Biribiri um lugar diferente para si, havendo um carinho especial da menina com esse "pequeno paraíso". Um ponto, digno de observação, é quando a menina diz acreditar que Biribiri tinha melhor vida do que o céu. Essa comparação é oportuna, se considerarmos que para as pessoas criadas sobre o dogma da fé, o céu é um lugar celestial, de gozo completo, um lugar calmo e tranquilo.

Logo após o relato dessa lembrança, a autora diz: "Guardo na memória até hoje a primeira vez que fui ao Biribiri." (1998, p.55). A importância de Biribiri como uma simples lembrança escrita não basta, é preciso que essa lembrança esteja viva, que a própria autora no presente intervenha, para marcar de forma explicita e forte o quanto essa lembrança é importante para si. Ė uma emoção que se vê prolongada até o presente, deixando claro para o leitor que está lendo suas memórias, que essa é uma lembrança muito importante, de valor inestimável.

\section{Construindo-se mulher}

O diário "Minha Vida de Menina" nos permite analisar a própria questão de gênero, da figura feminina, pois os relatos são escritos justamente por uma mulher. A obra revela o comportamento de uma adolescente que no fim do século XIX conseguia se diferenciar muitas vezes do padrão infligido à mulher na época. $A$ protagonista aponta as distinções de comportamento entre as figuras femininas do diário, como as primas, a avó, a mãe, colegas da escola e outras.

Helena foge ao padrão de recato e conservadorismo ao qual as mulheres estão submetidas, principalmente no aspecto do pensamento, pois enquanto muitas seguem os preceitos morais do bom comportamento e sonham com a ideia de casamento e viver para cuidar da casa, Helena possui o pensamento livre, independente, podemos dizer até transgressor para a época. A menina apresenta uma consciência que difere das outras, como se verifica no seguinte trecho: 
Mamãe às vezes diz que ela até deseja que eu fique preguiçosa; a minha esperteza é que a amofina. [...] Eu sei por que mamãe deseja que eu seja preguiçosa; é para viver metida em casa com ela, como Luisinha. Isto é impossível. Só essa ideia me horroriza (MORLEY, 1998, p.149).

O comportamento de Helena é sempre ativo, jamais condizente com a passividade. Ela demonstra um pensamento parcialmente liberto das amarras sociais presentes em Diamantina (é utópico pensar em uma mulher totalmente livre das amarras que a sociedade emprega), tanto que sua própria mãe deseja que ela não seja muito esperta. Helena muitas vezes consegue com suas ideias mostrar o paradigma social ao qual as mulheres estão submetidas e o que a sociedade espera das mesmas.

Ao confessar que se achava feia, Helena expõe um comportamento que foge totalmente do padrão atribuído à mulher ideal, com traços delicados, bem-vestida e bem-comportada. No entanto, encontramos em um dos relatos do diário, uma cena que mostra o interesse de um rapaz por Helena. Joviano, um normalista que está tendo lições de inglês com o pai de Helena fica apaixonado pelo jeito de ser da menina. É a própria irmã do rapaz, "Maricas", que conta o interesse do irmão por Helena:

\begin{abstract}
É porque seu Alexandre ainda não desconfiou que ele gosta mais de ouvir você rir e falar perto dele o dia inteiro. [...] Não se lembra daquela bobagem que você fez no dia que a levamos para a casa com aquela chuva? Você estava com umas botinas de elásticos arrebentados e encharcadas e da porta da rua foi sacudindo as pernas e atirando as botinas no corredor. Viano falou na mesa que sabe que vai ficar solteirão, porque só se casará com uma moça que faça aquele gesto perto dele e sabe que não a encontrará (MORLEY, 1998, p.201).
\end{abstract}

Os modos despachados de Helena despertam um fascínio no rapaz. De todas as mulheres de Diamantina a que lhe chama mais atenção é justamente Helena, por conta de seu comportamento natural, seu modo de ser. Esse trecho é importante para mostrar que Helena é vista pelo rapaz não apenas como uma mulher ideal, mas com os traços de uma menina alegre e espontânea. A espontaneidade é característica fundamental para entender a figura feminina idealizada em Helena Morley, que se opõe, por exemplo, a figura bem-comportada de suas primas. A ousadia de seus pensamentos e comportamentos tornam-na uma personagem que 
desconstrói a função social atribuída à mulher submissa e o fascínio que a transgressão dos modos de vida exercem sobre sua pessoa.

Em muitas ocasiões, vamos perceber em seu comportamento ações próprias de uma criança, de uma menina que quer se divertir e brincar. Em outros momentos, vamos encontrar atitudes e pensamentos de uma menina que está passando por uma transição, percebendo direta ou indiretamente que o mundo está mudando e também que alguns comportamentos e crenças nunca mudam.

\section{Considerações Finais}

As memórias de Helena Morley revelam as condições em que ela se encontra em meio à sociedade em que vive. Ilustra também as relações de parentesco tecidas ao longo do diário, que não foge das regras submetidas à memória feminina. Segundo Perrot, "os modos de registro das mulheres estão ligados à sua condição, ao seu lugar na família e na sociedade." (1989, p.15). Mais do que o registro da memória, o livro "Minha vida de menina" é um registo histórico ao mesmo tempo em que alcança um forte poder literário. Segundo Lima, "a memória é de imediato, um documento histórico, uma fonte historiográfica, que configurando-se por um correlato sensível do que foi vivido, alcança uma inscrição literária suplementar". (2006, p. 353).

Os acontecimentos e lembranças narrados no diário estão imbrincados de um forte desejo por parte de Helena de indagar o mundo, de questionar comportamentos, regras e modos impostos e praticados por sua família e pela sociedade de Diamantina. Como Schwarz, mesmo diz:

[...] o registro pelo registro, ou o passado pelo passado, não são com ela. Digamos que o cotidiano da família e da cidade passa pela vistoria de um espírito juvenilmente desejoso de notar e entender, que imprime aos episódios a tensão da racionalidade, bem acima da crônica provinciana. (1997, p.76).

Em "Minha Vida de Menina" apresentam-se desde as várias camadas sociais que compõe a província de Diamantina, até as relações de interesse que regem essa mesma sociedade. Um exemplo claro está nas disputas pela herança da avó materna de Helena Morley, bem como os ciúmes das primas ricas pela relação de carinho entre a avó e Helena. A relação é vista como algo de interesse no viés de 
Helena, já que ela pertencia à parte mais pobre da família. Passeiam pela obra também os vários tipos de religiosidade, desde a religião praticada pelos negros, como a católica e o próprio protestantismo.

Os questionamentos feitos por Helena no diário servem para ilustrar muitas vezes não apenas a própria identidade do povo de Diamantina, como do próprio povo brasileiro. Em dado momento, Helena indaga o seguinte: "Nós temos a mania de achar tudo que é de fora melhor do que o nosso. [...] O que é nosso não presta, só de outras terras é que é bom". (MORLEY, 1998, p.134). O teor espontâneo com que questiona algo tão importante como o olhar sobre o outro, acaba revelando a fina ironia de que se reveste seu discurso. O discurso da autora está longe de ser considerado de cunho nacionalista, mas sim de engendrar a compreensão de um mundo melhor em que as regras oficiais de comportamento vão sendo questionadas, revistas e repensadas. O pensamento de Helena ganha força na expressão que busca uma vida melhor, mais livre, podendo pensar-se a si mesma como mulher.

A prosa espontânea de Helena acrescida dos vários casos e histórias que abrangem o diário acaba tendo um forte teor poético. Uma poesia do cotidiano, da simplicidade, aliada aos assuntos que se analisados com todo o cuidado, mostram uma complexidade que foge da ideia de um simples diário adolescente.

\section{REFERENCIA CITADA}

MORLEY, Helena. Minha vida de menina. São Paulo: Companhia das Letras,1998.

SCHWARZ, Roberto. Duas meninas. São Paulo: Companhia das Letras, 1997.

LEJEUNE, Philippe. O pacto autobiográfico de Rousseau à Internet. Belo Horizonte: UFMG, 2008.

LE GOOF, Jacques. História e memória. Campinas: UNICAMP, 1990.

ROCHA, Clara Crabbé. O espaço autobiográfico em Miguel Torga. Coimbra: Livraria Almedina, 1977.

TABAK, Fani; FREIRE, Deolinda. Narrativa e memória. In: CASADORE, Francisco Mariani et al. (Org). Memória e cultura: entre o presente e o passado. Uberaba, MG: UFTM, 2009. 
PESAVENTO, S. J. O Mundo como texto: leituras da história e da literatura. História da Educação, Pelotas, v. 7, n. 14, p. 31-45, set. 2003.

LIMA, Luiz Costa. História. Ficção. Literatura. São Paulo: Companhia das Letras, 2006.

PERROT, Michelle. Práticas da memória feminina: A mulher e o espaço público. Revista Brasileira de História, n 18. Saõ Paulo: Anpuh- Marco Zero, 1989. 